\title{
Curriculum Emergence in a Postcolonial Society - Trinidad and Tobago
}

\author{
Leela Ramsook \\ The University of Trinidad and Tobago, Trinidad and Tobago
}

\begin{abstract}
Trinidad and Tobago, a twin island Republic in the Caribbean which was a British colony until 1962, inherited a system of education with prescribed school subjects such as English Language, English Literature, History, Mathematics and Science. This study investigated the emergence a new curriculum subject, Social Studies, on the national curriculum in a postcolonial society - Trinidad and Tobago. The main objectives of the study were to investigate the nature of the decision making that catapulted the emergence of the new school subject and the experiences of participants who were involved in its development. A hermeneutic phenomenological method in the qualitative paradigm was used to discover participants' experiences of the phenomenon - school subject emergence. The sample included eight persons who participated in the evolvement of the subject. Data collection instruments included face to face in-depth interviews, semi-structured interviews, memos, questionnaires, field notes and document analysis. Data were analysed using qualitative techniques of coding, forming categories/ sub-categories and discerning themes that emanated. The results revealed that an individual was responsible for the emergence of a new curriculum area, Social Studies, at both the primary and secondary levels in Trinidad and Tobago. The following themes evolved: 1. The Individual as Determinant of Curriculum Emergence 2. Subject Emergence for Nation Building. This research has implications for the emergence of new school subjects at different levels of the education system locally, regionally and internationally.
\end{abstract}

\section{Introduction}

In a retrospective commentary on the curriculum picture during the immediate post-colonial period in Trinidad and Tobago, a dual-island nation in the Caribbean, London [22] described the general scene as being in "ferment". This description is intended to capture the various changes in curriculum, and in particular school subjects, that were taking place in the new nation. The situation was in marked contrast to a curriculum picture that had not changed significantly for decades prior to political independence in 1962 [2].
The curriculum canvas in Trinidad and Tobago had remained staid for many years previously. The change, as other observers remarked, was perceived as a mechanism to bring about social and economic development in the new nation [2], [22]. It is in this atmosphere of change that a new school subject, Social Studies, emerged on the local scene. In fact, during the immediate post-independence period, the emergence of new subjects particularly at the secondary level, was a phenomenon in newly emergent states [22]. and the rationale offered for emergence, namely social and economic development [2] was almost always the same. In Trinidad and Tobago in particular, societal upheavals such as the Black Power Movement of the early 1970s imparted a degree of urgency in the change agenda, not only in socio-economic and political matters, but specifically moreso in regard to the type of education and curriculum which the school presented and the socialization offered in consequence. Core subjects included English and Mathematics which were institutionalized in all schools [22] but there were variations in subject offerings, which often depended on the availability of teachers and facilities. Different subjects might have been on offer, but Mathematics and English were compulsory across the board.

It was against this background that change took place. Some new subjects began to emerge, and by 1975 the list of new entrants on the canvas comprised Social Studies and Integrated Science. Information Technology emerged in later years. In a related context, Weiler [37] views such a change as "epistemological, theoretical and methodological transformation" (p. 19) and puts forward the argument that at the epistemological level, the question of "realms" of knowledge comes up for interrogation. Such changes, according to Bacchus [1], are rooted in a contestation of one kind or another grounded in a claim and display of power. Those in power, he argues, define and validate what is appropriate knowledge, a view confirmed by M. F. D. Young [38], who made the point that the authorities in power determine what "appropriate" knowledge is or should be.

\section{Theoretical framework}

Lester [19] asserts that, "A theoretical framework guides research activities by its reliance on a formal 
theory, that is, a theory that has been developed by using an established, coherent explanation of certain sorts of phenomena and relationships (p. 458). A study such as this cannot be undertaken without reference to earlier theories of how emergence might occur. In consequence the study investigated emergence theories propounded by Goodson [10] particularly, and his associates such as Anstead and Mangan [11], notwithstanding the contribution that may have been made by others. Goodson [9] developed a model of school subject emergence after extensive study of Rural and Environmental Studies, Biology and Geography in Britain. Other theories that inform this study include constructivism, curriculum theory, post-colonial theory and hermeneutic phenomenology.

\section{Purpose of the study}

The purpose of this research was to investigate the decision-making process that facilitated the emergence of Social Studies as a new curriculum area in Trinidad and Tobago. The school subject emergence event occurred more than three decades ago, and in the circumstance an interpretation of what happened and how, appeared justifiable using a hermeneutic phenomenological inquiry. The aim of the study was to illuminate details of participants' personal experiences about the phenomenon [8], school subject emergence - Social Studies, and to examine the nature of decision-making involved in the emergence trajectory.

\section{Research questions}

1. What was the nature of the decision making that catapulted the emergence of a new curriculum at both the primary and secondary levels in a postcolonial society?

2. What were the experiences of the participants who spearheaded the emergence of the new curriculum area?

3. What roles did the "personal" and the "biographical", as mentioned by Goodson play in the emergence of Social Studies?

The research questions are justified on the grounds that certain governmental policies, guided by the political directorate [38], had to be instituted before any attempt at curriculum introduction could be made in the existing national curriculum. In addition, particular individuals or groups had to be involved in the initiation, formulation, promotion and valorization of the new subject.

\section{Review of literature}

\subsection{Hermeneutic phenomenology}

Hermeneutic phenomenology is a method and theory based on the essence of meaning and interpretation [15], [14], [8]. In this connection, we are reminded that, "Hermeneutic research is interpretive and concentrated on historical meanings of experience and their developmental and cumulative effects on individual and social levels [18]. James B. Macdonald [32], encapsulates the idea thus: The fundamental human quest is the search for meaning and the basic capacity for this search is experiences in the hermeneutic process, the process of interpretation of the text (whether artefact, natural world, or human action). This is the search (or research) for greater understanding that motivates and satisfies us . . . It is an expression of the humanistic vision of life.

\subsection{Subject emergence in perspective}

The study of school subjects was validated by sociologists such as Musgrove [11] who advised investigators to, "Examine subjects both within the school and the nation at large as social systems sustained by communication networks, material endowments, and ideologies". Later, in 1971, M. F. D. Young [38] examined the "relationship between school knowledge and social control" [11], together with the status of school subjects. M. F. D. Young [38] suggested that the historical context should be an important element in the study of school subjects. Goodson et al. [11] recommended that researchers should focus on the perspective of teachers and expressed concerns about the illumination of professional groups on the social construction of school subjects (p. 6). Sociologists like M. F. D. Young and Bernstein affirmed the validity of research into "the historical" [17] and the sociological aspects of school subjects. But the area of howschool subjects emerge remained in a state of stasis. In consequence, the critical study of the subfield, curriculum emergence (and/ or decline) is relatively new.

\subsection{School subjects and curriculum change}

Goodson [10] demonstrates that curriculum emergence is fraught with continuous struggles among groups and individuals "away from the eyes of the public". School subjects "represent substantial interest groups" [11] and certain individuals, particularly teachers make concerted efforts to jealously guard their school-subject domain. Walford [36] agrees that the initiation of new subjects involves "explicit territorial conflict between various interest groups". As theorized by Goodson [9], Jephcote and Davies [16] confirm, Newer subjects, such as 
economics, have struggled to raise their status because they have often been perceived as a threat and because they have often been promoted by new and young teachers who have lacked institutional status. Potential for conflict arises either when the new encroaches on the subject matter of existing subjects or because of competition for time and resources or their impact on career development. Any curriculum change is viewed suspiciously by educators [9] and society. Tabulawa [33] observes that, in the case of Botswana, new curricula are perceived as a lowering of educational standards. Goodson and Marsh [12], describe the issue of school subjects as a "highly contested, fragmented and shifting terrain where the actors involved deploy a range of ideological and material resources as they pursue their individual and collective missions".

\subsection{The power of tradition}

In Trinidad and Tobago, the hierarchical stratification of knowledge and status of school subjects were inherited during the colonial period under British rule [2]. The situation which continues to persist demonstrates the depth and profundity of tradition, giving testimony to the view expressed by Kliebard [17], that, "old ideas . . . are habits, predispositions and deeply ingrained attitudes of aversion and preference".

Goodson [10] notes that there exists in England a "hierarchy of high-status examination subjects associated with revered academic traditions" that is difficult to challenge. M. F. D. Young [38] confirms, "The contemporary British educational system is dominated by academic curricula with a rigid stratification of knowledge". Against a highly contentious, competitive background, initiators of new school subjects are faced with a yeoman task of convincing stakeholders and the public at large about the validity of new subjects. The establishment or the move to establish new subjects on the national curriculum is met with scepticism and disdain. Kliebard [17] notes that the terrain of traditional school subjects is difficult to infiltrate, and continues to be an impregnable fortress as some subject areas have a long history of prestigious status, credibility, resources and protected territory. In his analysis of Goodson' theory, McLaren highlights Goodson's [10] notion that the academic tradition is strongly fortified and "certain select knowledges become sacrosanct and canonized".

\subsection{The hierarchical status of school subjects}

Goodson [10] declares that within school subjects, there is a clear hierarchy of status which is based partly on the assumption that certain subjects, the so called 'academic' subjects, are suitable for the 'able' students whilst other subjects are not. M. F. D. Young
[38] also alluded to the rigid stratification of knowledge in schools, which legitimizes certain kinds and categories of information. Jephcote and Davies [16] observe that in England, "Over time, the workings of different subject communities have led to the establishment of a hierarchy of school subjects", which is difficult to challenge. These subjects belong to certain interest groups that make concerted efforts to guard their territory and any deviation or modification is met with opposition. "Once the relative status of a singular subject is embedded in a curriculum structure it becomes fixed and difficult to alter" [16]. A similar pattern became established in Trinidad and Tobago, a former British colony. There is an acknowledged domain of time-honoured subjects, such as English, Mathematics, and Science which have been ascribed prestigious status. In fact, the research has shown that technical/ vocational subjects together with Social Studies are regarded as less reputable not only by intellectuals, but by the general populace [2].

In another context, in Australia, historical accounts of the Social Studies movement throughout the 1960s exemplify scholarly neglect implying that it carries low status. Furthermore, commentators have observed that relatively few American educators have written about Social Studies outside the United States, suggesting that the subject carried less credibility.

Another observation is that subjects are supported by a hierarchical structure within the school system, and this is ably sustained by educators, who have vested interests, particularly as subject specialists. Jephcote and Davies [16], in their study of economics in England suggest "The overall thrust of a subject community (or segments within it) is to seek to establish the subject and to insulate it from others so that, overall, there is loyalty to the subject". Research by Goodson [10] has shown that this is supported, reinforced and buttressed by curriculum departments, universities, professional organizations, and subject associations

\subsection{Shifting allegiances}

In some cases, practitioners have also shifted allegiance to newly emerging subjects to ensure that their personal space and jobs are protected. Paechter as cited in Jephcote and Davies [16] remark that, "Whereas the overall impact of subject communities is to preserve the status quo, in any particular cycle of innovation and change, there is a fear of being left behind". It is in this regard that Goodson [10] cites the case of Biology in England. He reports that while sound arguments were put forward in favour of the subject (Biology), there were also shifting allegiances towards a newly introduced subject, Environmental Studies. He demonstrates that some individuals have conflicting loyalties, changing intentions and individual agendas. 
Goodson and Marsh [12] posit that there are social movements comprising a shifting range of traditions represented by factions, whose importance changes over time. Jephcote and Davies, [16] agree that, "School subject communities are neither harmonious nor homogeneous and members do not necessarily share particular values, subject definitions and interests".

Alliances may shift whereby competing individuals and groups may come together to form strategic alliances in the interest of their personal and professional survival or advancement. In a related context, scholars seek to merge subjects to acquire the requisite status among educators and the wider society [37], [1]. For instance, in Hong Kong, in 1965, civics was transformed into economic and public affairs (EPA) to gain acceptance by local and overseas universities.

However, "civics was given a more academic orientation and higher status by merging with an established academic discipline, economics" [25]. This is also supported by Jephcote and Davies [16] who contend that "Subjects are made up of loose community of factions which in different ways, want to expand or defend particular versions of the subject”.

\subsection{Turf protection}

The protection of "turf" has been advanced as another feature in the subject emergence dilemma. Observers have noted that within educational organizations there are diverse identities, interests as well as conflicts, and some "entrepreneurs" cement their aspirations by establishing relationships with institutions [10]. Many professional associations are born from these intense conflicts among sub-groups, which are generally formed to protect certain subjects, clienteles and schools. Jephcote and Davies [16] posit that, "Not only are teachers' identities in important ways constituted by their specialist subject and its status, from physics to physical education, but their natural interests, such as pay, promotion and conditions are interlinked with its fate". Subject groups are able to further their interests, debates and arguments especially about retaining traditional curriculum. For example, during negotiations for the introduction of Environmental Studies in England, many geographers vociferously voiced their objections to the planned removal of Geography [10]. The proponents argued that they had laboured to gain academic respect, and built a discipline. Goodson [10] reports, "The establishment of geography - 'how geography was rendered a discipline' - was a protracted, painstaking and fiercely contested process". The notion of the role of turf protection in subject emergence might also be understood in the example of Economics in the United Kingdom (UK) education system. For instance, in the UK, Economics was already ingrained at the Advanced level examination as a matriculation requirement for university. It suggests that the subject was protected even at the level of the university. That support system served to protect Economics in multiple ways from being 'subsumed' into Social Studies. Goodson [10] emphasizes the "parts played by teachers, academics, and other interested groups" [16], and the universities in the protection of subjects.

A similar battle was also waged in the case of Science. Jephcote and Davies [16] explain, "There has, for example, been deeply-rooted contestation of ground among school science subjects, including the coming and going of general science and the conditional acceptance of combined science". The terrain is described by McLaren [10] as "turf warfare" and the emergence of new subjects will always be met with severe challenges. In an analysis, McLaren [10] observes that he (Goodson) argues that curriculum change is "nothing short of turf warfare among teachers and scholars for the sake of acquiring power, status and economic security". This is clearly demonstrated in Goodson's study of Geography in England, which showed serious antagonisms and contestations by subject specialists when environmental education was introduced. Goodson's analysis of the conflicts generated, demonstrates "how an academic hierarchy carefully protected within the cloistered and sequestered terrain of traditional knowledge zealously guards its turf against possible encroachments from putatively lower-status subject groups and collegial outsiders" [10]. Any new subject is surrounded by major controversy and is regarded as 'inferior' and subservient to the inherently ingrained examination system and academic tradition.

\subsection{Establishing identity and utilitarianism}

Another issue in the emergence debate has to do with the role of universities. In fact, universities via subject scholars and specialists, not only define the classification of subjects but also the standards that teachers must uphold. They therefore dictate the criteria for admission to universities, ultimately protect their subject domain [12], and simultaneously promote the status and identity of particular disciplines. Jephcote and Davies [16] posit that "Structures exist to defend identities and to exclude 'illegal immigrants' together with the powerful integrating force of explicit cultural elements". These high-status subjects, which are validated by the examination system, maintain predominance and are guarded relentlessly by scholars and teachers alike. Interestingly, in Trinidad and Tobago, even today, Social Studies is not offered as a subject at Caribbean Advanced Proficiency Examination. The situation continues to prevail even though there are academic scholars in the domain, and Social Studies as well as 
specializations in the area are now being offered at the university level.

\subsection{Curriculum and state legitimization}

School subjects may also emerge in the context of what Weiler [37] has described as compensatory legitimation by the state. He argues that subject emergence also has to be understood as "concerted tactics and mechanisms for compensatory legitimation". The state tries to compensate for legitimation discrepancies, in order to maintain power [37], by consciously manipulating the system, and one sure way to do this is through education and by extension curriculum change and, or manipulation. Particularly in post-colonial societies, like Trinidad and Tobago, the state has to maintain its legitimacy "by providing for the general population, who continued to demand, among other services, an education which would increase their opportunities for social and economic mobility" [37]. In the circumstance, the introduction of new subjects may serve as a panacea in the state legitimation process. A rationale for curriculum transformation in postcolonial societies therefore, is to create national unity and identity [1], [37, but it is also a political investment for the State which serves as a source of accountability and a type of quality assurance to the public. In Nigeria, for example, government convinced the populace that the initiative to introduce Basic Science in 1962 and Social Studies in 1963 was "to build a strong, united and dynamic nation" [27]. Apart from imparting knowledge and providing valuable information necessary for life, Social Studies was deemed as the mechanism for helping students to inculcate desirable social habits needed for economic survival and nation building. However, Weiler [37], invites citizens to reconceptualise the relations between politics, knowledge, and change as hegemonic practices which are reinforced through the curriculum, and on this score, he advises that the population should lobby for a more equitable society.

\section{Data collection methods}

I conducted multiple one-on-one in-depth interviews with each participant to unearth individualized experiences. Rubin and Rubin [29] agree with Creswell's [6] notion that this type of "oneon-one interview is a data collection process in which the researcher asks questions to and records answers from only one participant in the study at a time". Confidentiality of data and anonymity of participants were assured. I personally transcribed all information verbatim and converted them into readable text. Those were returned to participants for verification of the accuracy of the data. In order to fortify credibility of the data gathered, I further used questionnaires, document analysis, memos, field notes and journal entries. Triangulation of data [7] serves tomaintain rigour [28], minimize researcher bias and ensure credibility [5]. The various applications have led to a situation described by

Cohen et al. [5] in which it is claimed that the researcher "mediates between different meanings" [35] to construct the lived experiences of individuals. Commentators on this methodology have argued that a hermeneutic phenomenological approach is one that captures the narrative accounts of participants, and how they reflect and express their experiences. Gadamer, [8], for example, made the point that interviews allow the researcher to unearth the "lived experiences" of the participants. The method has the potential to generate new understandings of complex multidimensional human phenomena and interactions [26].

For these reasons, the participants in this study were carefully chosen in that they are individuals who have all experienced the emergence phenomenon in question. This therefore is the type of context that would benefit from the use of purposeful sampling [23], [21]. since only certain persons were part of the

emergence process. As such eight participants or key informants formed the sample, a justifiable number for studies such as this. Throughout this research, they are referred to as P1, P2 . . P8 respectively, as indicated in the Table 1 below.

Table 1. Data on participants

\begin{tabular}{|l|l|}
\hline Positions Held by Participants & $\begin{array}{l}\text { Coded } \\
\text { Names } \\
\text { Used }\end{array}$ \\
\hline Chief Education Officer & $\mathrm{P} 1$ \\
\hline Permanent Secretary & $\mathrm{P} 2$ \\
\hline School Supervisor & $\mathrm{P} 3$ \\
\hline Curriculum Officer & $\mathrm{P} 4$ \\
\hline School Principal & $\mathrm{P} 5$ \\
\hline Teachers' College Lecturer & $\mathrm{P} 6$ \\
\hline $\begin{array}{l}\text { Head of Department/ Teacher - } \\
\text { Secondary }\end{array}$ & $\mathrm{P} 7$ \\
\hline Author/Teacher - Secondary & $\mathrm{P} 8$ \\
\hline
\end{tabular}

\section{Data analysis procedures}

Merriam [23] defines data analysis as "the process of making sense out of data . . . consolidating, reducing, and interpreting what people have said and what the researcher has seen and read". It is a process she argues of "making meaning" by coding [20]. In this study, data analysis was a cyclical process and conformed to the approach Merriam [23] describes as "recursive" and "dynamic". That is to say I conducted data analysis from inception, and as such it was tied to the data collection process itself.

The technique adopted facilitated clearer understanding and deeper analysis as well as made the study more manageable. The approach is consistent with analysis in qualitative research [24], [6] whereby there may be heavy dependence on one or more participants such as in this study. 
The data analysis procedure suggested by Lichtman [20] was used. This is comparable with procedures advocated by Miles, Huberman and Saldana [24]; Creswell [6]; Merriam [23], for hermeneutic phenomenological studies like this. Lichtman [20] advocates "Three C's of Data Analysis: Codes, Categories, Concepts" (Themes)". She also outlined a detailed six-step approach for generating concepts/themes (see Figure 1 below). (I added the word themes for consistency and to clarify the word 'concepts' in this study). Lichtman [20] explains that the qualitative researcher is allowed decisions about analysis based on discretion and intimate involvement in the study.

\section{Constructing themes}

\begin{tabular}{|l|}
\hline Step 1. Initial coding \\
Step 2. Revisiting initial coding \\
Step 3. Developing an initial list of categories or \\
central ideas \\
Step 4. Modifying your initial list based on \\
additional reading \\
Step 5. Revisiting your categories and \\
subcategories \\
Step 6. Moving from categories into concepts \\
(themes) \\
\hline
\end{tabular}

Figure 1. A Six-Step Process to Generate Themes [20]

I examined the data repeatedly in great detail to determine commonalities and linkages in order to form conceptual categories. These, I correlated, compared and synchronized with memos, field notes and journal entries, and documents which added to my understanding and interpretation. If, however, there were issues about the meaningfulness of the data, field notes and memoing added supplementary information or generated further questions. Also, based on consensual agreement I was able to telephone or email participants for clarification of information. I remained aware of and engaged in "bracketing" [15] my personal preconceived notions, prejudices and assumptions, an exercise Husserl [15] described as "epoche". With reiterative re-examination of data, I revised some preliminary categories and potential interpretations, which I construed in an unconfirmed manner. I then reviewed and re-constructed codes and categories based on additional information and subsequent investigations. The final themes were derived from the categories through reiterative reading and analysis.

\section{Results and findings}

As the study unfolds, I explained the major themes that evolved from the data, with relevant interpretation, discussion and analysis as demanded by the methodology of hermeneutic phenomenology. These were guided by the literature and the research questions which were "helpful in understanding the results of the study ... in analysing and reporting the data" [6]. Each theme that emanated was explicated, interrogated, analysed and discussed with relevant verbatim quotations. Hatch [13] recommends "enough detail and actual data to take the reader inside the social situation under examination". Two major themes that evolved are as follows: 1 . The Individual as Determinant of Curriculum Emergence 2. Subject Emergence for Nation Building. All interviewees indicated that Social Studies emerged in an effort to minimize the impact of colonialism and promote allegiance to Trinidad and Tobago. This was also confirmed in documents by Seepersad and Beddoe [31] and the Draft Plan for Educational Development in Trinidad and Tobago 1968-1983 [34]. Participants have used expressions such as patriotism, nationalism, national consciousness, love of country, nationhood, loyalty, civic mindedness and sense of belonging which can be encapsulated in the theme 'Subject Emergence for Nation Building'. All key informants credited Participant 1 (P1) for the emergence, introduction, growth and development of Social Studies in Trinidad and Tobago, and the data gathered points to the individual as epitomizing the role of leader, change agent and activist who operated "like a bull in a China shop". With aggression and determination, the individual simultaneously engaged in curriculum development, curriculum intervention, curriculum introduction and curriculum implementation. During every phase he provided astute leadership as confirmed by every participant. Below are excerpts of conversations with the various participants who elucidated the many roles the individual assumed in the emergence of Social Studies as a new curriculum area. Statements by the participants convey the essence of meaning [35] and experiences of the participants. Participant 2 stated, P1 was an important officer in the whole area of curriculum development . . . development of the Social Studies curriculum and ... its implementation in the schools". Participant 3 (P3) remarked, "It (Social Studies) could not have happened without P1 ... he dealt with all the weaknesses". Participant 4 (P4) elucidated, "P1 made Social Studies into a respected subject". Participant 5 (P5) added, "P1 was the curriculum for Social Studies". Participant 6 (P6) indicated, "P1 was the mastermind, the soul ... Without him Social Studies would be lost". Participant 7 (P7) observed, "If there is somebody to be noted as Mr Social Studies . . . it was P1". Participant $8(\mathrm{P} 8)$ noted, "It had to happen . . . with P1, it (Social Studies) couldn't fail". P1 indicated that nation building was at the heart of this contribution. He personally described his input with the expression, "I made the word flesh!" This Biblical terminology epitomizes the essence of meaning [35], and the major theme "The Individual as Determinant of Curriculum Emergence", a posture which was validated by all participants. The various subheadings below have 
been used to further convey the significant contributions of $\mathrm{P} 1$, which have been confirmed by each participant.

\subsection{Captains}

He established captains or the Biblical term "Apostles" to spread the message of the viability of Social Studies not only to teachers but to students and the community." He affirmed, "I went to the schools . .. I established 8 captains ... I call them Apostles ... to develop the curriculum and spread the word among the teachers first".

\subsection{Role of the University}

He collaborated with the University of the West Indies to publish information to aid teachers. The involvement of the university added credibility to the subject. P1 confirmed, "There were publications coming out of the university which were distributed to all and sundry in the schools".

\subsection{Resources for Teachers}

While the published information was disseminated to schools, it was P1 who ensured that the materials and curriculum guides were not just stored in cupboards, but were utilized by the teachers. "Teachers were provided with resources that I (P1) made available".

\subsection{The Importance of Examinations}

P1 emphasized, "I knew that we had to put an exam, not only at secondary but primary also ... I got the national committee for tech-voc (technical vocational) education to certify the exam (secondary). So, we set an exam ... a and when they performed on it, they got certification". The role of P1 extended beyond Trinidad and Tobago. The regional body, Caribbean Examination Council (CXC, 2013) [3], designated him the title "the "Father" of CSEC (Caribbean Secondary Education Certificate) Social Studies" (p. 18) [4], because of his vision and significant contribution. P1 confirmed, The Caribbean Examination Council (CXC) . . . came to me (as Chief Education Officer) with the question: Is Social Studies 'desirable and feasible' ... I must say they (CXC) were very much affected positively by the pioneering work that I had done in Trinidad ... The committee of 5, myself included, recommended to the CXC Board that it (Social Studies) is both 'desirable and feasible' He added, We produced a draft syllabus ... and (it was) circulated among the Caribbean countries. But it was rooted in the experience of Trinidad which I led . . . That syllabus went out in 1981 and the first examination (for secondary schools) by CXC was done in 1982 and they asked me to be Chief Examiner - a position that I held for more than 10 years. He exclaimed, I did not only concentrate on Junior Secondary and Senior Comprehensive ... I worked with the primary schools ... developed curriculum guides and worked with schools in every division. The following year, I think it was April or March, 1982 Social Studies appeared on the Common Entrance Examination (that is, assessment for transition to secondary school).

\subsection{Teacher Support}

Teachers were provided with support to build their confidence and competence in the implementation of the subject. "We were providing

teachers with the know-how - what to teach, how to teach it and how it will be tested." P1 was "in the trenches" and personally engaged in the activities such as conducting workshops to encourage teacherbuy-in. He questioned, "How do you think I helped existing teachers acquire skills?

Through workshops". I conducted workshops for primary and secondary teachers in all the educational districts". He continued, "When I was Chief Examiner, I used to go out for a 3 day workshop I did with all the teachers. I encouraged a lot of national communication among the interested people in the Caribbean countries.

\subsection{National Quiz}

P1 indicated that he initiated a national quiz for both primary and secondary schools. He ensured that it was televised not only for awareness by the populace but to build the credibility and status of the new curriculum subject, Social Studies. I introduced . .. the TRINTOC (Trinidad and Tobago Oil Company) Oil Quiz in this country ... at the primary level, the Junior Secondary level or the sixth form debate. That was carried on television, sponsored by TRINTOC". The aim was to sensitize the population about Social Studies, engage in nation building and promote patriotism.

He concluded, I knew we had a good thing to sell and I was determined to get it going. That was the essence of my experience . . . Everything was beautiful in my experience. I have no regrets ... I have it (passion) all the time ... My source of happiness is right now. You go to $\mathrm{CXC}$ and say: What is the popularity of the subject? - 90,000 English, same number for Mathematics, and 48,000 or 49,000 for Social Studies - third highest ranking! Where did this come from? How did this happen? ... from a humble beginning ... Now it is equal to any other subject.

In essence P1 was the quintessence of the Social Studies curriculum emergence. His input demonstrated the critical role that the "personal and the biographical", as mentioned by Goodson [9], may play in the emergence of Social Studies in Trinidad 
and Tobago. We note that academic subjects are formed and established by those in power and have the resources and political will to do so [9], [36]. But as an individual, P1 demonstrated the power, capacity and capability and passion for Social Studies. While he had support, political and otherwise, he had a keen interest, vision, mission and goal from which he never deviated. He said, "If you are committed to something and you have a goal, you don't want to hear about the detractors. I used to pay them little heed". He was assertive, confident, committed, dedicated, creative and aggressive in the emergence issue. I created the poem below for "evocative representation" [24] to demonstrate the contribution of participant 1 (P1).

\section{The Individual}

The Individual as Determinant of Curriculum Moved resolutely like a pendulum

He was like a lion on the prowl

Never deterred by external growls

He cast a spell and captured his prey

And creditably engineered the introduction of

Social Studies his way.

\section{Conclusion}

It can be concluded that an individual was the leitmotif for the genesis of a locally constructed school subject as core curricula at both primary and secondary schools in Trinidad and Tobago. The subject has developed into an examinable area at the regional level, the Caribbean Examinations Council (CXC), and has acquired status on par with other traditional school subjects. The research has implications for curriculum history and the emergence of new curriculum areas at different levels of the education system locally, regionally and internationally.

\section{Recommendations}

Over a period of time, school subjects such as Latin and Greek have declined and no longer exist as curricula subjects in the country. Subjects such as Geography and History which were highly revered traditionally are now diminishing in status, and technology is currently creating a new wave of interest. These topics will form interesting areas of research. Also, the influence of a professional association in promoting the credibility of a school subject may be investigated.

\section{References}

[1] Bacchus, K. (1990). Curriculum development and education in developing countries. Educational Review, 42 (3), 287-301.
[2] Campbell, C. (1996). The young colonials: A social history of education in Trinidad and Tobago 1834-1939. Kingston, Jamaica: The Press University of the West Indies.

[3] Caribbean Examinations Council (2013), CSEC report (2013). St Michaels, Barbados. Retrieved, June 16, 2014 from https://www.cxc.org/?q=node/ 8225

[4] Caribbean Examinations Council (2013), Ken Seepersad "Father" of CSEC Social Studies. The Caribbean Examiner, 11 (2), 18-21.

[5] Cohen, L., Manion, L., \& Morrison, K. (2007). Research methods in education. New York, NY: Routledge.

[6] Creswell, J. W. (2012). Educational research: Planning, conducting and evaluating quantitative and qualitative research (4th ed.). Upper Saddle River, NJ: Pearson.

[7] Denzin, N. K., \& Lincoln, Y. S. (Eds.) (2011). Handbook of qualitative research. (4th ed.). Thousand Oaks, CA: Sage.

[8] Gadamer, H. G. (1976). Philosophical hermeneutics. (David E. Linge, Ed and Trans.). Berkekey, CA: University of California Press.

[9] Goodson, I .F. (1981). Becoming an academic subject: patterns of explanation and evolution. British Journal of Sociology of Education. 2 (2) 162-180.

[10] Goodson, I. F. (1993). School subjects and curriculum change. London: Falmer Press.

[11] Goodson, I. F, Anstead, C. J. \& Mangan, M. M. (1998). Subject Knowledge: Readings for the study of school subjects. London, UK: Routledge.

[12] Goodson, I. F. \& Marsh, C. J. (1996). Studying school subjects. London: UK: Falmer Press.

[13] Hatch, A. (2002). Doing qualitative research in education settings. New York, NY: State University of New York Press.

[14] Heidegger, M. (1962). Being and time. New York, NY: Harper. (Original work published 1927).

[15] Husserl, E. (1970). The idea of phenomenology. The Hague, Netherlands: Martinus Nijhoff.

[16] Jephcote, M., \& Davies, B. (2007). School subjects, subject communities and curriculum change: the social construction of economics in the school curriculum. Cambridge Journal of Education, 37 (2), 207-227.

[17] Kliebard, H. (1987). The struggle for the American curriculum 1893-1958. Boston, MA: Routledge and Kegan Paul.

[18] Laverty, S. M. (2003). Hermeneutic phenomenology and phenomenology: A Comparison of historical and methodological considerations. International Journal of Qualitative Methods, 2 (3). Retrieved March 3, 2013 from 
http://www.ualberta.ca/ iiqm/backissues/2_3final/pdf/lave rty.pdf

[19] Lester, F. K. (2005). On the theoretical, conceptual and philosophical foundations for research in mathematics education. The International Journal of Mathematics Education,37, 457-467.

[20] Lichtman, M. (2006). Qualitative research in education. A user's guide. Thousand Oaks, CA: Sage.

[21] Lincoln, Y. S., \& Guba, E.G. (1998). Naturalistic inquiry. Newbury Park, CA: Sage.

[22] London, N. A. (1997). Socio-politics in effective curriculum change in a less developed country: Trinidad and Tobago. Curriculum Inquiry, 27 (1), 63-79.

[23] Merriam, S. B. (2009). Qualitative research: A guide to design and implementation. Revised and expanded from qualitative research and case study applications in education. San Francisco, CA: Jossey-Bass.

[24] Miles, M. B., Huberman, M. A. \& Saldana, J. (2014). Qualitative data analysis. A methods sourcebook (3rd ed.). Beverly Hills, CA: Sage.

[25] Morris, P., Mc Clelland, G., \& Ping Man, W. (1997). Explaining curriculum change: Social studies in Hong Kong. Comparative Education Review, 41 (1), 27-43.

[26] Moustakas, C., (1994). Phenomenological research methods. Thousand Oaks, CA: Sage.

[27] Ogunyemi, B. (2010). Curriculum politics in the changing fortunes of Nigerian Social Studies. International Journal of Education, 2 (2), 1-12.

[28] Patton, M. Q. (1990). Qualitative research and evaluation methods (3rded.). Thousand Oaks, CA: Sage.

[29] Rubin, H. J. \& Rubin, I. S. (2005). Qualitative interviewing: The art of hearing data. Thousand Oaks, CA: Sage.

[30] Saldana, J. (2009). The coding manual for qualitative researchers. Washington, DC: Sage.

[31] Seepersad, K., \& Beddoe, I. B. (1985). Origins and development of Social Studies education in Trinidad and Tobago. Caribbean Curriculum 1

(1)

[32] Slattery, P. (2006). Curriculum development in the postmodern era. New York, NY: Taylor and Francis.

[33] Tabulawa, R. T. (2009). Education reform in Botswana: reflections in policy contradictions and paradoxes. Journal Comparative Education, 45 (1), 87-107.

[34] Trinidad and Tobago. Ministry of Education (1974). Draft plan for educational development in Trinidad and Tobago 1968-1983. Port of Spain, Trinidad: Author.
[35] van Manen, M. (1990). Researching lived experience: Human science for an action sensitive pedagogy. London, Ontario: The University of Western Ontario.

[36] Walford, G. (1985). The construction of a curriculum area: Science in society. British Journal of Sociology of Education, 6 (2), 155-

171.

[37] Weiler, H. (1990). Curriculum reform and the legitimation of educational objectives: The case of the Federal Republic of Germany. Oxford

Review of Education 16, (1), 15-28.

[38] Young, M. F. D. (1971). Knowledge and control: New directions for the sociology of education. London, UK: Collier-Macmillan. 